\title{
Two new cave-dwelling harvestmen from Western Australia (Arachnida: Opiliones: Assamiidae and "Phalangodidae")
}

\author{
William A. Shear \\ Department of Biology, Hampden-Sydney College, \\ Hampden-Sydney, Virginia 23943, U.S.A.
}

\begin{abstract}
Two new species of laniatorid harvestmen have been collected in the biologically significant caves of the Cape Range Peninsula, Western Australia. Dampetrus isolatus sp. nov. (Assamiidae) has reduced eyes but is otherwise not especially adapted for a subterranean life; it has been collected in several Cape Range caves. Glennhuntia glennhunti gen. et sp. nov. ("Phalangodidae") is a minute, highly evolved troglobite known only from Camerons Cave. Both species are likely rainforest relics. Some notes are provided on the Australian fauna of the harvestman Infraorder Grassatores.
\end{abstract}

\section{INTRODUCTION}

Hunt (1991) noted that fewer than 200 species of the arachnid order Opiliones (harvestmen, phalangids) had been described from Australia, a number he estimated to be no more than $20 \%$ of the total fauna. Indeed, Hunt himself was the first and last productive resident harvestman specialist in Australia, who had personally described a substantial portion of those species. His untimely demise put an end to a succession of fine papers on the systematics of several Australian taxa, most notably the Triaenonychidae, Neopilionidae and Megalopsalididae.

While taking notice of the richness of the Australian fauna of the laniatorid infraorder Grassatores, Hunt published little on them. Four families of the infraorder, Assamiidae, Podoctidae, Zalmoxidae and "Phalangodidae" have been recorded from Australia. Four zalmoxid species, all in the genus Zalmoxis Sørensen, are known from Queensland, New South Wales, and the Kimberley Plateau of northern Western Australia. Austribalonius Roewer, with a single named species, is the only podoctid genus. The Assamiidae of Australia are dealt with in the remarks below under the description of the new species, and likewise the "phalangodids" under the description of Glennhuntia glennhunti.

Specimens are deposited in the Western Australian Museum (WAM), Perth, and I thank Mark Harvey for making them available to me for study. Comments from two anonymous reviewers materially improved the manuscript.

Glenn Hunt (1944-1999), whom I knew only through correspondence, had produced a series of outstanding systematic papers on Australian opilionids, working on a fauna that was almost unknown (compared to its potential richness) at the time he began. He recognized the two species described below as new and determined the assamiid as a species of Dampetrus Karsch. I'm honoured to be able to dedicate this brief paper to his memory

\section{SYSTEMATICS}

\section{Family Assamiidae Sorensen}

Subfamily Dampetrinae Sorensen

Genus Dampetrus Karsch

Dampetrus isolatus sp. nov.

Figures 1-3

\section{Material Examined}

Holotype

6, cave C-345, Cape Range peninsula, Western Australia, Australia, $22^{\circ} 05^{\prime} \mathrm{S}$, $113^{\circ} 59^{\prime} \mathrm{E}, 6$ September 1989, R.D. Brooks (WAM T40676).

\section{Paratypes}

Australia: Western Australia: Cape Range peninsula: $1 \%$, cave $C-103,22^{\circ} 07^{\prime} \mathrm{S}, 113^{\circ} 59^{\prime} \mathrm{E}, 19$ August 1989, M. East (WAM T40675); 1 \&, cave C-167, 22 $09^{\prime} \mathrm{S}, 114^{\circ} 00^{\prime} \mathrm{E}, 21$ July 1991, S. Brooks (WAM 92/2125).

\section{Other Specimens}

Australia: Western Australia: Early instar assamiid specimens were taken in the following caves in the Cape Range, but because of their immaturity, cannot be assigned to this species with certainty: 1 juvenile, Cave C-187, 22 $09^{\circ} \mathrm{S}, 114^{\circ} 00^{\prime} \mathrm{E}$, 
20 June 1989, M.S. Harvey (WAM T40672); 1 juvenile, Cave $C-65,22^{\circ} 06^{\prime} \mathrm{S}, 114^{\circ} 00^{\prime} \mathrm{E}, 27$ June 1989 , W.F. Humphreys (WAM T40673); 1 juvenile, Cave C-179 (Wombat Hole Cave), $22^{\circ} 06^{\prime} \mathrm{S}, 113^{\circ} 58^{\prime} \mathrm{E}, 7$ July 1989, R.D. Brooks (WAM T40674); 1 juvenile, Cave C-271, 22 ${ }^{\circ} 00^{\prime}$ S, $114^{\circ} 04^{\prime} \mathrm{E}, 8$ July 1998, R.D. Brooks (WAM T40679).

\section{Diagnosis}

Dampetrus isolatus differs from previously described species of the genus in the strong mesolateral spines of the palpal patella. While these spines are present on some other Dampetrus, they are only about one-third the size of those of the new species.

\section{Description}

\section{Male}

Scute length $3.0 \mathrm{~mm}$, greatest scute width 2.1 $\mathrm{mm}$, total length about $3.7 \mathrm{~mm}$. Colour uniform deep orange. Anterior margin of scute with five spines, two lateral on each side and one median spine; lateral spines subequal to median spine, angled slightly lateral (Figure 1). Row of 7-8 pointed granules just posterior to marginal spines. Scute lateral margins diverging posteriorly to scute area four; slightly rebordered, with submarginal row of granules; sharp angle in margin opposite eye tubercle. Eye tubercle $0.4 \mathrm{~mm}$ wide, $0.15 \mathrm{~mm}$ long, low, with 3 or 4 indistinct acute granules over each eye. Eyes small, lightly pigmented. Carapace area with scattered granules. Scute area 1 with paired low, densely granular swellings, larger, spine-like granule at each summit. Area 2 likewise. Area 3 narrower, swellings low, but with two large granules. Area 4 similar to 3 , but additional granule anterior to pair also enlarged. Posterior margin of scute with 12-14 enlarged, acute, spine-like granules; posterior margins of free tergites similar.

Chelicerae (Figure 2) robust, not sexually dimorphic, basal article with pronounced crest of enlarged granules. Palpus (Figure 3) with trochanter bearing single large spine; femur with ventral row of 9 spines, seventh and ninth from base smaller than others, femur armed distolaterally with large spine; patella with two large mesal spines, each bearing short macroseta, with two much smaller lateral spines, small mesoapical tubercle; tibia with two mesolateral macrosetae borne on low spines, long distal lateral spine with macroseta nearly equal its length, subtended by small setose tubercle, series of five lateral spines with 3 proximal to major spine, 2 distal, tarsus with two lateral and two mesal macrosetae on low tubercles, lateral margin with six additional spines, claw sickle-shaped, nearly as long as tarsus.

Legs typical of Dampetrus. Fourth coxae densely covered in blunt, elongate granules. Tarsal articles: $6(3), 12,6,7$.

Unfortunately the penis of the only male was lost during the dissection process.

\section{Female}

Scute length $2.75 \mathrm{~mm}$, greatest scute width 2.0 $\mathrm{mm}$, total length about $3.1 \mathrm{~mm}$. Otherwise as described for male.

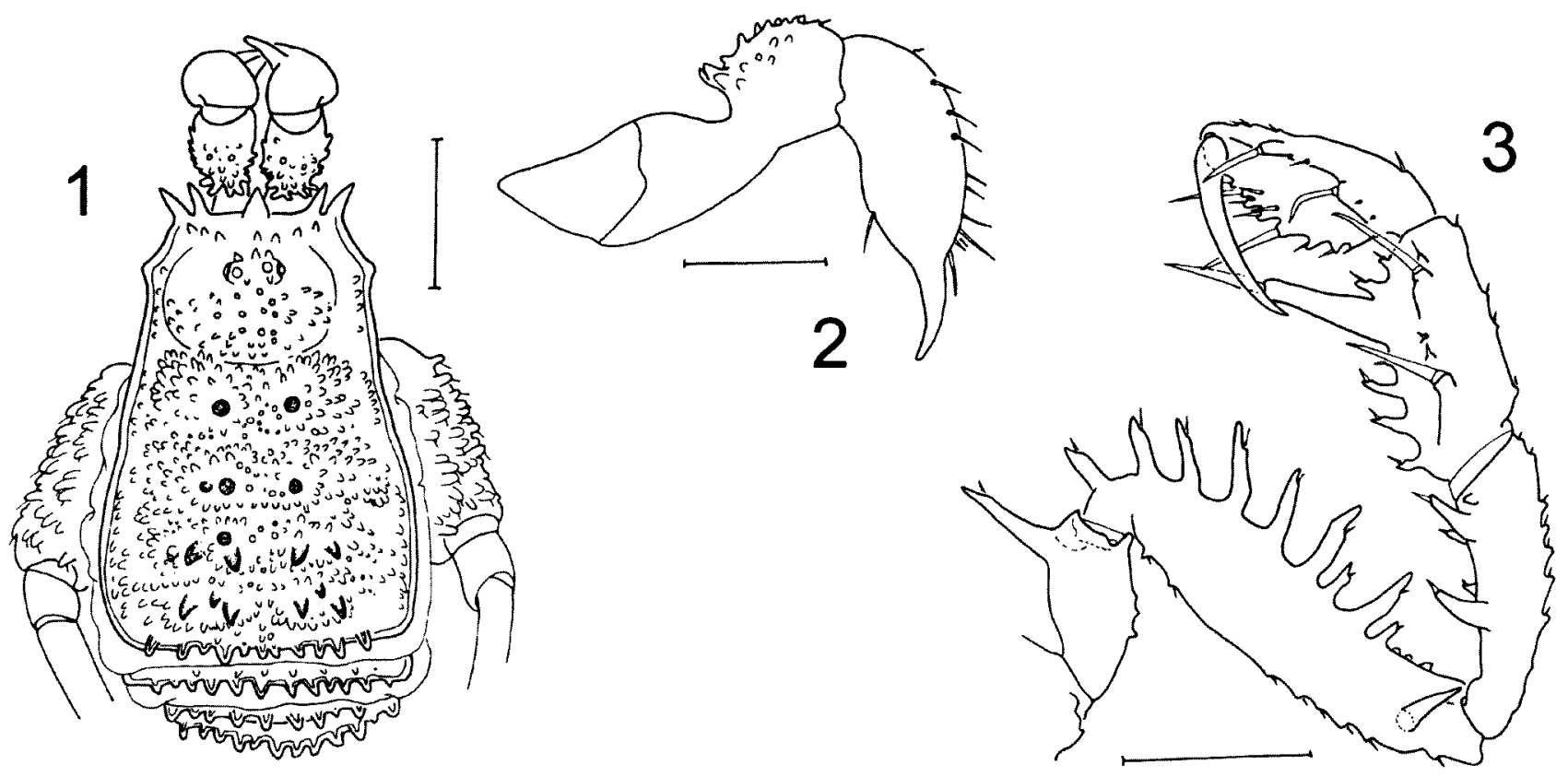

Figures 1-3 Dampetrus isolatus sp. nov., male: 1, dorsal view; 2, chelicera, lateral view; 3, palpus, mesal view. Scale lines: $1.0 \mathrm{~mm}$ (Figure 1), $0.5 \mathrm{~mm}$ (Figures 2, 3). 


\section{Remarks}

Eleven species of Australian assamiids have been described and another three undescribed species have been noted (Hunt, 1991). These fourteen species are unevenly distributed among seven genera: Dampetrus has seven species and the genera Euwintonius Roewer, Dampetrellus Roewer, Eudampetrus Roewer, Cardwella Roewer, Octobunus Roewer, Metamermeris Roewer and Anjolus Goodnight and Goodnight are monotypic (of these genera, it would appear from descriptions and illustrations that only Metamermeris may be distinct from Dampetrus).

The five named Dampetrus species were surveyed and illustrated by Forster $(1949,1955)$. All are from eastern Australia (Queensland, New South Wales), except for the type species, Dampetrus australis Karsch, which was recorded by its describer (Karsch, 1880) as being from "Western Australia," without further detail. Forster (1955) found that Karsch's two cotype specimens actually represented two species, the nominal one, and one later named by Sørensen (1886) as D. granulatus Sørensen. Both of these species are found in Queensland and have not been collected since in Western Australia, so the questions originally raised by Roewer (1923) about the provenance of Karsch's original material remain. By "Western Australia" Karsch may not have been referring to the present state of Western Australia, but to a western section of Queensland. In any case, two undescribed species of Dampetrus have turned up in the Kimberley Plateau (Hunt, 1991), so the genus does actually occur within the boundaries of the state, though these records are more than 1500 kilometres from the localities where the new species described below was collected.

The family Assamiidae was set up by Sorensen in 1884. The family is known from Subsaharan Africa (rare in South Africa), India (including Sri Lanka and the Himalaya of Nepal), southeast Asia, the Indonesian archipelago, and Australia/New Guinea. Roewer returned several times to the Assamiidae after his initial survey of 1923, most importantly in 1935, adding more subfamilies (some transferred from the old, highly inclusive Phalangodidae) and genera, and deleting others. Almost all the added genera were monotypic, so the species/genus ratio remains less than 2.0; in a survey of harvestman genera Adriano Kury (Museu Nacional, Rio de Janeiro; personal communication, 2000) found that 248 available generic names in Assamiidae include only 435 species, for a ratio of 1.75. Not that this is an unusual situation in the order; the fantastically prolific Roewer classified animals as if they were inanimate objects; a limited set of characters was employed and any novel combination resulted in a new species, genus or family. Fortunately, the family Assamiidae is one that can be well circumscribed, with the removal of the originally discordant elements that have been separated as the family Tricommatidae Roewer.

The family is easily distinguished from all others by 4-8 marginal spines on the front edge of the carapace (Figure 1). The raptorial palpi (Figure 3), often rather small and held crossed-over, are of the "grabber" type, with a sickle-like claw closing against a spiny tarsus, which in turn closes against the spiny tibia, particularly a distinctive, large, distolateral spined process. The patella may be unspined or bear two large spines, and the femur carries a row of strong ventral spines that give it a serrate appearance. Martens (1977) provided a codified system for describing the palpal spination and noted that the assamiids he studied had a unique structure in the male penis called a "Stacheltrichter": a coarsely scaly, eversible funnel surrounding the glans spine. Only a few forms have been examined for this particular feature, but it has been illustrated by Kauri (1985) for African species and by Suzuki $(1970,1985)$ for southeast Asian species. While the noted combination of carapace, palpal and genitalic characters will pick out assamiids, only the genitalic character can be regarded as reliable on its own - carapace spines or the palpal configuration occur separately in some obvious non-assamiids.

Almost nothing has been published on phylogeny of Dampetrus or of the Assamiidae. Originally, assamiids were supposed to be close to the Podoctidae, another predominantly southeast Asian group, but Adriano Kury (personal communication, 2000) has tentatively allied them with the Stygnopsidae, Cosmetidae and Gonyleptidae of Middle America. Roewer (1935) divided the family into subfamilies, but these have proven to be highly artificial and probably do not represent monophyletic groups of genera.

The Australian forms are in the subfamily Dampetrinae, which Roewer (1935) attributes to himself, but which was named as a family by Sorensen in 1886. In 1935, Roewer characterized the Dampetrinae as having no pseudonychium on legs 3 and 4, 3 segments in the first distitarsus, smooth claws throughout, concealed stigmata, toothed palpal femora, and lacking median spines on the carapace. Unfortunately this definition is far from exclusive. As presently composed, the Dampetrinae are found in Australia, New Guinea, and Thailand (Suzuki, 1985).

The genus Dampetrus is endemic to Australia, but some of the many New Guinea genera (as well as all but one of the other Australian assamiid genera) named by Roewer are likely synonyms. Five of the seven reported species are from Queensland and New South Wales (but see above for D. australis), and two undescribed ones were collected in rainforest patches in the Kimberley district of 
northern Western Australia. Hunt (1991) implies that there are many other species.

\section{Etymology}

The name refers to the isolation of this species in caves in an arid environment, as well as the distance separating it from any known congeners.

\section{?Family Phalangodidae Simon}

Glennhuntia gen. nov.

\section{Type Species}

Glennhuntia glennhunti sp. nov.

\section{Diagnosis and Description}

As for the single species, below.

\section{Etymology}

The name of the genus honours the late Glenn Hunt, Australian harvestman specialist extraordinaire.

\section{Glennhuntia glennhunti sp. nov. Figures 4-8}

\section{Material Examined}

\section{Holotype}

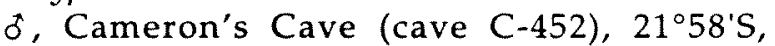
$114^{\circ} 07^{\prime} \mathrm{E}$, Cape Range peninsula, Western Australia, Australia, 17 May 1995, B. Vine (WAM T40678).

\section{Paratypes}

Australia: Western Australia: $1 \%$, same locality, but 11 January 1994, R.D. Brooks (WAM 94/10); 1 q, same data, but 26 October 1994 (WAM T40677, BES: 2549).

\section{Diagnosis}

Glennhuntia glennhunti differs from any other known Australian grassatorid harvestman by its small size, eyelessness and depigmentation, and unique male genitalia.

\section{Description}

Male

Scute length $0.85 \mathrm{~mm}$, greatest scute width 0.90 $\mathrm{mm}$, total length about $1.37 \mathrm{~mm}$. Colour pale yellowish white, cuticle thin, leathery, nearly transparent. Scute (Figure 4) finely rebordered, margins diverging slightly, evenly to posterior margin. Scute faintly and finely roughened, without spines or other sculpture, carapace region set off by low transverse depression, scute not visibly divided into areas. Eyemound low, about $0.09 \mathrm{~mm}$ wide, without sculpture or spines. Eyes entirely absent. Free abdominal tergites without sculpture or spines.

Chelicerae (Figure 5) smooth, not sexually dimorphic. Palpus (Figure 6) with small spined tubercle ventral on trochanter; three basal large spined tubercles on femur, femur armed mesodistally with large spined tubercle; patella with single pair of lateral and mesal spined tubercles; tibia with two lateral and single mesodistal spined tubercle, tarsus with two pairs of lateral and mesal spined tubercles, claw stout, acute, curved, less than one-fifth length of tarsus.

Legs long, very slender, not ornamented. Tarsal formula: 2, 3, 4 (3), 5 (4). Femur of leg 4 sigmoid (Figure 4), otherwise unmodified.

Genital operculum twice as long as wide. Penis as Figures 7,8 ; ventral plate narrowly rounded at apex, densely setose; dorsally excavate near tip (may be artifactual); glans reflexed when expanded, evidently without spine, small papillae surround duct opening; with "wings" of acutely scaled cuticle seemingly supported by lateral sclerotized extensions.

\section{Female}

Scute length $1.00 \mathrm{~mm}$, greatest scute width 1.00 $\mathrm{mm}$, total length about $1.25 \mathrm{~mm}$. Tarsus 4 with 4 (3) segments. Genital operculum as wide as long. Ovipositor short, with 5 dorsal and 4 ventral setae. Otherwise as described for male.

\section{Remarks}

As for the "Phalangodidae," this wastebasket family will continue to provide frustration for systematists for years to come. While a few uniform, defensible family-level taxa have been carved out of it in the past few decades (Zalmoxidae, Samoidae, Stynopsidae, Stygnommatidae, Fissiphalliidae, etc.) it remains a huge undigested and perhaps indigestible lump to which any grassatorid harvestman not obviously fitting in one of the better-defined families is assigned. In my view, the name Phalangodidae can only be applied to a relatively small number of genera clustered around Phalangodes Tellkampf (eastern United States) and limited to the north temperate zone. The hundreds of other genera now placed in this family will have to find homes elsewhere.

With the removal of Zalmoxis Sørensen to the Zalmoxidae, only Bogania Forster and Spalicus Roewer remain as nominal Australian "phalangodid" genera, The form of the male genitalia (Cantrell, 1980) patently excludes Bogania from a more strictly defined Phalangodidae. Hunt (1991) referred to Bogania as a dominant genus in eastern Australia, but only five species have been described (Forster, 1955; Cantrell, 1980). Spalicus oeditarsus Roewer (New South Wales; Roewer, 1949) was described in the "phalangodid" subfamily 


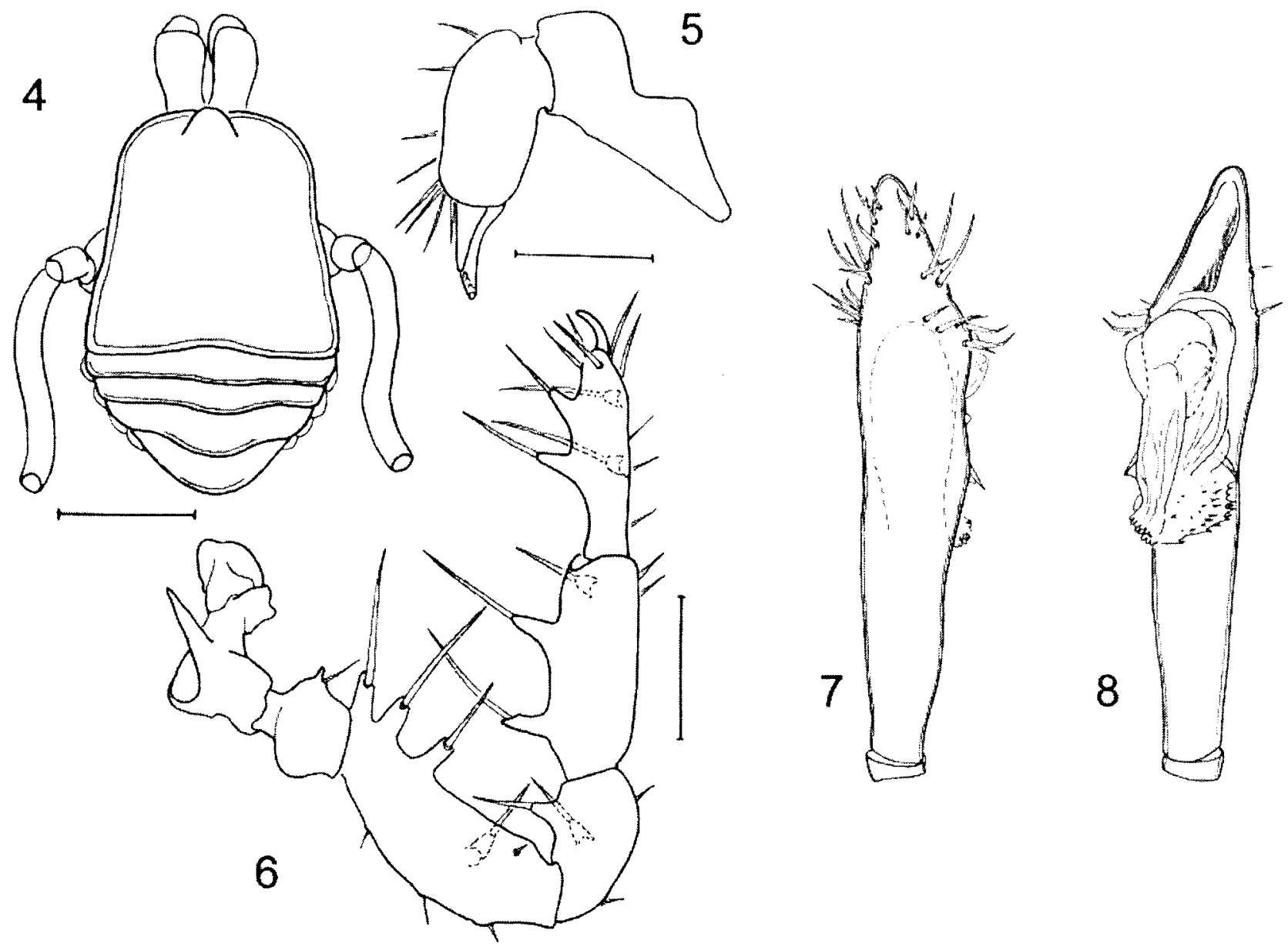

Figures 4-8 Glennhuntia glennhunti gen. et sp. nov., male: 4, dorsal view; 5, chelicera, mesal view; 6, palpus, lateral view; 7 , penis, subventral view; 8 , penis, subdorsal view. Scale lines: $0.5 \mathrm{~mm}$ (Figure 4), $0.25 \mathrm{~mm}$ (Figures $5,6)$.

Phalangodinae, parts of which now make up a separate family Samoidae, but an examination of the male genitalia of $S$. oeditarsus would be required to determine its position.

Glennhuntia glennhunti could be confamilial with Bogania, but as a tiny, reduced troglobite, few characters are available on which to base such a conclusion. There are similarities (and differences!) in the male genitalia, and the sexual dimorphism in the genital operculum is the same in the two genera. However, this is not the context in which to try to sort out this situation. Let me instead say that the new taxon is being described here primarily to provide a name for use in ecological studies and in an ongoing campaign for the preservation of the unique fauna of the karsts of the Northwest Cape.

\section{REFERENCES}

Cantrell, B.K. (1980). Additional Australian harvestmen (Arachnida: Opiliones). Journal of the Australian Entomological Society 19: 241-253.
Forster, R.R. (1949). Australian Opiliones. Memoirs of the National Museum of Victoria 16: 59-89.

Forster, R.R. (1955). Further Australian harvestmen (Arachnida: Opiliones). Australian Journal of Zoology 3: $354-411$.

Hunt, G.S. (1991). Opiliones (Arachnida) of the Kimberley rainforests, Western Australia: 295-297. In N.L. McKenzie, R.B. Johnston, P.G. Kendrick (eds), Kimberley rainforests. Surrey Beatty and Sons, Chipping Norton.

Karsch, F. (1880). Arachnologische Blätter. Zeitschrifte geschichte Naturwissen 53: 373-409.

Kauri, H. (1985). Opiliones from Central Africa. Koninklijk Museum voor Midden-Afrika, Tervuren, Belgium, Annales Zoologische Wetenschappen 245: 1-168.

Martens, J. (1976). Opiliones aus dem Nepal-Himalaya. III. Oncopodidae, Phalangodidae, Assamiidae (Arachnida). Senckenbergiana Biologica 57: 295-340.

Roewer, C.Fr. (1912). Die Familien der Assamiiden und Phalangodiden der Opiliones-Laniatores. Archiv fiur Naturgeschichte 78: 1-242.

Roewer, C.Fr. (1923). Die Weberknechte der Erde. Gustav Fischer, Jena. 
Roewer, C.Fr. (1935). Alte und neue Assamiidae. Weitere Weberknechte VIII. Veröffenlichungen aus den Deutsche Kolonial-und Uebersee-Museum in Bremen 1: 1-168.

Roewer, C.Fr. (1949). Uber Phalangodiden I. (Subfam. Phalangodinae, Tricommatinae, Samoinae). Weitere Weberknechte XII. Senckenbergiana 30: 11-61.

Sorensen, W.E. (1884). Opiliones Laniatores (Gonyleptides W.S. Olim). Musei Hauniensis. Naturhistorisk Tidsskrift 3: 555-646.

Sorensen, W. E. (1886). Arachnida Opiliones. In L. Koch and E. Keyserling, Die Arachniden Australiens, vol. 2. Bauer and Raspe, Nürnberg.
Suzuki, S. (1970). Report on a collection of opilionids from Nepal. Journal of Science of the Hiroshima University, Series B, Division 1 (Zoology) 23: 29-57.

Suzuki, S. (1985). A synopsis of the Opiliones of Thailand (Arachnida). I. Cyphophthalmi and Laniatores. Steenstrupia 11: 69-110.

Manuscript received 21 July 2000; accepted 10 November 2000 . 